\title{
Dividend taxation and Corporate investment: A Comparative Study Between the Classical System and Imputation System of Dividend Taxation in the United States and Australia
}

\author{
Bhavish Jugurnath ${ }^{\mathrm{a},}$, Mark Stewart ${ }^{\mathrm{a}}$ and Robert Brooks ${ }^{\mathrm{b}}$ \\ ${ }^{a}$ RMIT University, School of Economics and Finance, Melbourne 3000, Australia \\ ${ }^{b}$ RMIT University, Research and Development Unit, Melbourne 3000, Australia
}

\begin{abstract}
In recent times a number of countries have initiated some important tax reforms to eliminate the distortions of double taxation. In this context, Australia adopted a dividend imputation system in 1987, while the US employed the 1986 Tax Reform Act (TRA). The analysis in this paper examines the effects on the level of corporate capital investment, on proxies for corporate tax rates, financial leverage, liquidity, capital intensity and firm size after controlling for the tax reforms. The empirical results provide evidence that: (1) dividend imputation as introduced in Australia is an effective way to reduce the distortions caused by the traditional system of taxation. (2) Compared with the TRA, dividend imputation has been better able to positively stimulate corporate capital investment. (3) TRA effect on corporate investment is more pronounced in the US for firms having a net operating loss. (4) Individual tax rates play a role in corporate investment decisions in both the US and Australia.
\end{abstract}

JEL classification: E62; F21

Keywords: Corporate investment, Dividend imputation, Tax Reform Act

Corresponding author. Tel + 61-3-9387 5980; fax 61-3-9925 5595

Email address: Bhavish.Jugurnath@rmit.edu.au

We thank Heather Mitchell and Tim Fry for their very helpful suggestions. 


\subsection{Introduction}

Taxation of dividends raises fundamental tax policy issues. The United States (US) is still one of the few remaining countries to employ the classical system of taxation that fully taxes distributed corporate earnings twice, once at the corporate level, and again at the individual level. Kari and Ylä-Liedenpohja (2002) state that classical corporation tax regards corporations and their owners as separate tax entities and therefore doubletaxes their income, first the corporation and then the owners, on dividends and realised capital gains. Such a tax system discriminates against the incorporation of business ideas, restrains the supply of equity finance necessary for their economic utilisation, reallocates resources from the corporate to the unincorporated sector and thus causes an efficiency loss to the whole economy.

The potential misallocation of resources and the subsequent loss of efficiency associated with the traditional corporate tax systems has been the subject of much research. For example, Harberger (1962) demonstrates that the traditional double taxation on corporate profits causes capital to flow out of the corporate sector, thereby artificially reducing capital investment by corporations. This bias against capital investment in the corporate sector in turn results in inefficient pricing and consumption of corporate products. Gravelle (1991) indicates that these distortions can have significant macroeconomic effects, including lower growth of GNP.

To eliminate the distortions associated with double taxation, Australia has adopted an imputation tax system in 1987. This taxation approach works by refunding corporate taxes through franking ${ }^{1}$ credits associated with dividend payments. Morck (2003) recently points out that the US double taxation of corporate income continues to affect share values and distorts savings and investment flows. In comparison to Australia's 1987 dividend imputation system ${ }^{2}$, the US reformed its corporate tax system in 1986 with the Tax Reform Act (TRA). The TRA eliminated much of the preferential treatment afforded to capital gains. This Act also contained several other provisions which potentially could affect investment. The Investment Tax Credit (ITC) originally

\footnotetext{
${ }^{1}$ A franking account tracks income earned by the company on which corporate tax has been paid. This is used only in an imputation system.

${ }^{2}$ For a background discussion of Australia's dividend imputation system, see Hamson, D., Ziegler, P. 1990. The impact of dividend imputation on firms' financial decisions. Accounting and Finance 30, 29-53.
} 
enacted in 1962 was repealed, depreciation lifetimes were generally extended and to compensate these changes the statutory tax rate was reduced. Australia, implemented similar changes to corporate taxation within a few years of the US reforms. (Table 1 gives a detailed summary of the changes in corporate tax rates and individual tax rates in both countries) These reforms in the US may have disrupted the strategic decision making of investors, who frequently found themselves either racing to invest in order to claim an investment tax credit or delaying investment so as to qualify for a credit after it became available.

The US TRA was passed with significant, but mixed tax incentive effects on investment. This reform is widely believed to have increased the marginal cost of new investment to firms while in Australia the introduction of dividend imputation and the associated tax benefit to shareholders was an attempt to stimulate corporate investment. This combination of different dividend taxation systems (classical and imputation) and different tax reforms (the American TRA and the Australian introduction of dividend imputation) offers an ideal setting for this study. By treating the tax changes in these countries as experiments in tax and investment policy, this study compares their relative and incremental effects. Although economic conditions differed over time between these countries, by including general economic and firm specific measures in an econometric model, it is possible to control for the various non-tax variables that affect corporate investment. This would enable the effects of the tax reforms to be examined in isolation. The aim of this study is to examine and provide empirical evidence of the effects of the US TRA and the Australian dividend imputation on corporate investment.

The remainder of the paper is organised as follows. Section two provides a review of the theoretical and empirical literature related to dividend taxation and investment and subsequently develops the research hypotheses. Section three presents the empirical research design of the study. Section four reports the empirical results. Finally, section five provides the overall conclusions of the study. 


\subsection{Literature Review}

\subsection{Literature related to Dividends and Investment}

The impact of taxes on corporate financial decisions has been the focus of much research since Modigliani and Miller (1958). There has been a recurrent controversy in the finance and economics literature about the interdependence of investment and financial variables. Modigliani and Miller (1958) argued that the value of the firm depends only on its investment policy and not on the method of financing investments. This conclusion is the corollary of their assumption of perfect capital markets. The opposing view would argue that capital markets are sufficiently imperfect that the firm must consider the method of financing in its investment decisions. To this end, Dhrymes and Kurz (1967), assuming imperfect capital markets, studied a large cross section of American firms from 1951 to 1960. Using single equation and simultaneous equation models, they reported substantial interdependence between investment and dividend decisions. Dhrymes and Kurz then fitted their model as a cross-section for each of the years from 1951 to 1960 , and although the independent variables were generally significant they did not always have the predicted sign. However, when the equations were estimated using simultaneous equation methods, the signs of the independent variables were fairly consistent with predictions ${ }^{3}$. Their findings led them to caution against the use of single-equation models of investment and dividend behaviour.

Probably the most widely cited of the studies that tests the relationship between investment and financing is Fama (1974). Fama used a sample comprising 298 US firms over the period 1946 to 1968 . Instead of using cross-section data he chose to fit his regressions as time series for individual firms and then compared the results across firms. Fama found that investment had the expected negative effect on dividends in about 60

\footnotetext{
3 This conclusion was supported by Mueller, D. 1967. The firm decision process: An econometric investigation. Quarterly Journal of Business and Economics, 5887. who conducted a study similar to that of Dhrymes and Kurz, even using a similar time period except that he omitted external financing and included advertising, research and development expenditures as independent variables. In general his results were similar to those of Dhrymes and Kurz. However, Higgins, R. 1972. The corporate dividend-savings decision. Journal of Financial and Quantitative Analysis 7, 1527-1541., questioned the findings of Dhrymes and Kurz with some new evidence from American companies during the period 1961 to 1965 . His study concluded that dividends were a function of profit and investment but that investment did not depend on dividends. His results were consistent with the Miller and Modigliani theorem.
} 
percent of his regressions, but that dividends had the expected negative effect on investment in only about 40 percent of his time series regressions. He concluded that this supports the Modigliani and Miller (1958) position and that there is no evidence for the interdependence of dividend and investment decisions. Fama (1974) suggested that the difference in his results with those of Dhrymes and Kurz (1967) arises because they omitted certain lagged variables, constrained the parameters of the dividend and investment models to be equal for all firms, and chose inappropriate deflators. Fama admits, however, that his own results may be influenced by sampling errors that obscure the true relationship between dividends and investment. Hence the empirical evidence must be considered inconclusive ${ }^{4}$.

\subsection{Literature related to Dividend Imputation and Tax Reform Act}

Though the introduction of dividend imputation in numerous countries and the TRA in the US has been the focus of many studies, research which focuses on the impact of investment flows under both Australian imputation and the American TRA is limited.

Bellamy (1994) using Australian firm data from 1987 to 1992, examined dividend drop-off for dividends with and without credits attached ${ }^{5}$. Bellamy, found that the dividend drop-offs for dividends with credits attached were significantly higher than for those without credits. That is, there was a positive and significant relationship between the amount of the credit attached and the amount of dividends paid, implying that corporations with tax credits increase their dividends in order to pass these credits to shareholders. Bellamy finds support for this notion with the increase in use of dividend reinvestment plans since the introduction of dividend imputation.

Heming (1994) also investigated the impact of dividend imputation on payout ratios in Australia. He uses a sample of 145 firms with data for a ten year period either

\footnotetext{
${ }^{4}$ For a detailed discussion on the literature of dividend and investment see McCabe, G. 1979. The empirical relationships between investment and financing: A new look. Journal of Financial and Quantitative Analysis 14, 119-135., McDonald, J., Jacquillet, B., Nussenbaum, M. 1975. Dividend, investment and financing decisions: Empirical evidence on french firms. Journal of Financial and Quatitative Analysis 7. and Peterson, P., Benesh, G. 1983. A re-examination of the empirical relationship between investment and financing decisions. Thr Journal of Financial and Quantitative Analysis 18, 439453.

${ }^{5}$ Taxation of dividends implies that the drop-off in price when a stock becomes ex-dividend should be less than the value of the dividend. Thus, the elimination of the double taxation system is expected to cause the drop-off ratio to move closer toward one
} 
side the introduction of the dividend imputation system. Employing a univariate statistical approach, Heming found statistically higher payout ratios in the postimputation period. However, Heming suggested that this finding is unlikely to be the result of the imputation system since he finds no difference in the increase of the payout ratio for firms that paid dividends with full imputation credits and those that had only partial imputation credits. Following Heming (1994), Black, Legoria and Sellers (2000), using firm data in Australia and New Zealand from 1982 to 1991, investigated the impact of dividend imputation on corporate capital investment. Employing a pooled cross section approach, Black et al. found statistically higher corporate investment in both countries. In addition separating the firms between high-dividend paying and lowdividend paying firms, they found that dividend imputation are more pronounced for high-dividend paying firms. Black et al. find support for the notion that the "traditional" double tax on corporate distribution increases the cost of equity capital to the corporate sector and creates a bias against investment by the corporate sector.

Studies on the impact of TRA and capital flows are also limited. Abrutyn and Turner (1990) use survey methods to analyse the impact of the TRA on dividend payouts. The results report reactions and expectations of how CEOs thought they would respond to the $1986 \mathrm{TRA}^{6}$. Their results indicate that $85 \%$ of CEOs surveyed expected no change in the dividend payout ratios as a result of the 1986 TRA. Eleven percent of CEOs indicated their firms would pay out a higher percentage of after tax profits in the form of dividends.

Bolster and Janjigian (1991) examined shareholder wealth effects and dividend policy changes with respect to the 1986 TRA using a sample of 883 American firms. High dividend yield stocks ${ }^{7}$ significantly outperformed low dividend yield stocks in the period surrounding the passage of the 1986 TRA. Anticipation of the Act caused much of the price adjustment to occur prior to the formal passage. Their findings indicate that dividends increase monotically throughout the time period 1984 to 1989, with no

\footnotetext{
${ }^{6}$ The time frame of the survey, early in 1988, coincides with the first year that the tax changes were complete. The results report reactions and expectations of how CEOs thought they would respond to the 1986 TRA. Actual responses could be completely different if investor demand appears to warrant a change in dividend payout ratios.

${ }^{7}$ Bolster and Janjigian define dividend payout ratios as total dividends divided by total after tax earnings and examine aggregate dividend payouts, focusing only on the mean and median aggregate dividend payments.
} 
significant change after the passage of 1986 TRA. Bolster and Janjigian concluded that the existence of tax clienteles did not appear to significantly impact corporate dividend decisions. In line with Bolster and Janjigian, Means, Charoenwong and Kang (1992) investigated the changes in dividend yield ${ }^{8}$ patterns with the introduction of the 1986 TRA in US. The authors hypothesised that the introduction of the TRA would cause an increase in dividend yields and a decrease in capital gains yield. Their findings indicated that dividend yields trended downward over the period 1984 to 1986, while after 1986 dividend yields moved upwards again.

The aim of this study is to add to the previous American and Australian literature by testing simultaneously the effect of the Australian dividend imputation and the American TRA on corporate investment. Specifically, this study undertakes to test the following hypotheses:

Hypothesis 1: As part of the tax reform that permitted the introduction of imputation, Australia also introduced a capital gains tax. Prior to these changes Australia operated under a classical taxation regime. The elimination of double taxation of corporate income and the introduction of a capital gains tax in Australia presents a unique opportunity for analysing the effects of a change in the taxing regime. However, the potentially counteracting effects of dividend imputation and capital gains tax makes it difficult to predict the directional impact on capital investment, hence two hypotheses are developed.

$\mathbf{H}_{1} \mathbf{A}$ : If the positive effects of dividend imputation exceeded the negative effects of the new capital gains tax, then the net effect of the tax reform on corporate capital investment would be positive.

$\mathbf{H}_{1} \mathbf{B}$ : If the negative effects of the new capital gains tax exceeded the positive effects of dividend imputation, then the net effect of the tax reform on corporate capital investment would be negative.

Hypothesis 2: Unlike Australia, the US still operates under a classical taxation system and as such corporate income is taxed twice. However, in 1986 the US introduced a Tax Reform Act which repealed the investment tax credit from its original enactment in 1962. The TRA theoretically should have negatively effected investment, as potential

\footnotetext{
${ }^{8}$ Their calculations of yearly dividends involve summing monthly dividend yields divided by the summation of monthly total yields.
} 
investment projects would be required to generate higher cash flows before becoming feasible. This leads to the second hypothesis.

$\mathbf{H}_{2}$ : The introduction of the TRA in 1986 in US had a negative impact on corporate capital investment.

To this end, the work of Heming (1994), Black et al.(2000), Bolster and Janjigian (1991) and Means et al.(1992) is extended to a sample of American and Australian firms operating under the TRA and dividend imputation respectively.

\subsection{Other factors affecting Corporate Investment}

While the primary motivation of the study was to investigate the impact of Australian imputation and American TRA on investment, it is also necessary to control for certain non-tax determinants of corporate investment. Black et al. (2000), Callihan (1994), Gupta and Newberry (1997b), Gilchrist and Himmelberg (1995) and Stickney and McGee (1982), for example, have specified a number of significant non-tax factors, which affect a firm's investment. The most important of these variables are included in the empirical model as follows:

- Financial Leverage;

- Liquidity;

- Investment;

- Capital intensity; and

- Firm size;

Debt to Equity Ratio (DE): Financial Leverage may also affect corporate investment ${ }^{9}$. Gupta and Newberry (1997a) suggest that the tax deductibility of debt would imply that there is a negative relationship between effective tax rates and the level of leverage. In other words, differences in marginal tax rates may be driving firms' capital investment and financing decisions. Moreover Black et al.(2000) point out, in an efficient market it is reasonable to assume that capital is provided to firms with better

\footnotetext{
${ }^{9}$ The relationship between financial leverage and investment is discussed fully by Lintner, J. 1956. Distribution of income of corporations among dividends, retained earnings and taxes. American Economic Review 46, 97-118., Meyer, J., Kuh, E. 1957. The investment decision: Harvard University Press. Boston. and Meyer, J., Glauber, R. 1964. Investment decisions, economic forecasting and public policy: Harvard University Press. Boston..
} 
investment opportunities. Hence inclusion of DE will control for the effect of financial leverage.

Operating Cash Flow (OPR): This is a measure of the firm's ability to raise funds internally to finance its capital expenditures/investments ${ }^{10}$. Gilchrist and Himmelberg (1995) find evidence that cash flow affects a firm's capital investment. Thus, it can be hypothesised that a firm with higher operating cash flow will be better able to raise capital investment.

Capital Intensity Ratio (CIR): Stickney and McGee (1982) recognise that the existence of accelerated depreciation provisions and investment allowances meant that the effective tax rates should be inversely related to investment in depreciable assets. Therefore, it is expected that capital investment by firms with high capital intensity would likely be more affected by the tax reforms than firms with relatively lower capital intensity.

Size (SIZE): As argued by Black et al. size of the firm also affects the ability of the firm to raise capital and investment. This is measured as the natural logarithm of total assets.

Lagged Investment (LINV): Corporate investment can also be correlated with investment over succeeding years. The inclusion of a lagged term of PPE is included as a measure of capital investment for the prior year scaled by total sales to be consistent with the dependent variable.

\footnotetext{
${ }^{10}$ Anderson, L. 1964. Corporate finance and fixed investment: An econometric study: Division of Research, Graduate school of Business Administration, Harvard University. and Lintner, J. 1967. Corporate finance: Risk and investment, Determinants of investment behaviour. National Bureau of Economic Research: New York. provide a discussion of internal liquidity as a potential determinant of investment.
} 
Table 1: Tax rates in US and Australia

\begin{tabular}{|c|c|c|c|c|}
\hline & \multicolumn{2}{|c|}{ USA } & \multicolumn{2}{|c|}{ Australia } \\
\hline Year & $\begin{array}{c}\text { Maximum } \\
\text { Corporate } \\
\text { Tax Rate }\end{array}$ & $\begin{array}{c}\text { Maximum } \\
\text { Individual } \\
\text { Tax Rate }\end{array}$ & $\begin{array}{c}\text { Maximum } \\
\text { Corporate } \\
\text { Tax Rate }\end{array}$ & $\begin{array}{c}\text { Maximum } \\
\text { Individual } \\
\text { Tax Rate }\end{array}$ \\
\hline 1982 & $46 \%$ & $50 \%$ & $46 \%$ & $60 \%$ \\
\hline 1983 & $46 \%$ & $50 \%$ & $46 \%$ & $60 \%$ \\
\hline 1984 & $46 \%$ & $50 \%$ & $46 \%$ & $60 \%$ \\
\hline 1985 & $46 \%$ & $50 \%$ & $46 \%$ & $60 \%$ \\
\hline 1986 & $46 \%$ & $50 \%$ & $46 \%$ & $60 \%$ \\
\hline 1987 & $34 \%$ & $38.5 \%$ & $49 \%$ & $57 \%$ \\
\hline 1988 & $34 \%$ & $28 \%$ & $49 \%$ & $49 \%$ \\
\hline 1989 & $34 \%$ & $28 \%$ & $39 \%$ & $49 \%$ \\
\hline 1990 & $34 \%$ & $28 \%$ & $39 \%$ & $48 \%$ \\
\hline 1991 & $34 \%$ & $31 \%$ & $39 \%$ & $47 \%$ \\
\hline 1992 & $34 \%$ & $31 \%$ & $39 \%$ & $47 \%$ \\
\hline
\end{tabular}

\subsection{Research Design}

This section provides a description of the data set used in this paper and the procedure used to construct the dependent variable and the regressors, as well as including descriptive statistics. The initial testing of the research hypotheses is carried out by adding to the empirical model certain variables which proxy for a firm's tax status and other determinants of corporate investment.

\subsection{Dependent variables}

Corporate Investment (INV): Following Kinney and Trezevant (1993), capital investment is measured as the change in gross Property, Plant and Equipment (PPE). In addition, similar to Black et al. (2000), a firm's annual Research and Development (R\&D) expenditures is added to its change in PPE for each year. Next, consistent with Black et al. investment is scaled by total sales, to obtain a measure of investment that controls for inflation and growth. Therefore investment is measured by the change in PPE R\&D divided by sales.

\subsection{Independent variables}

Tax rates (ITR and CRT): As Black et al. point out, Individual Tax Rates (ITR) and Corporate Tax Rates (CRT) could impact on capital investment in a number of ways. Individual rates indirectly affect the corporate cost of capital through their impact on 
required pretax rates of return. Corporate taxes clearly decrease the net after-tax cash flows from an investment. Hence these two variables are included in the model.

Tax reform (TREF): This is a dummy variable which will indicate the effect of the tax reform. TREF is set 0 prior to the effective date of tax reform and 1 otherwise. Therefore, for Australian data TREF is set 0 prior to 1987 (year of the introduction of dividend imputation in Australia) and 1 for years after 1987, while for the US, TREF is set 0 prior to 1987 (year when TRA came into effect) and 1 for years after 1987. As discussed before a positive relationship is expected between dividend imputation and investment while a negative relationship is expected between the TRA and corporate investment.

Net Operating Loss (DNOL): The effects of tax rate changes on capital and investment are likely to be conditioned on a firm's marginal tax rate. In order to control for firms having an operating loss which might then not have to pay any corporate tax, firms are classified as $\mathrm{NOL}^{11}$. More specifically NOL is used as a dummy variable whereby it is set to 1 for firms with an operating and 0 otherwise. Black et al. argue that this is the best proxy measure for low marginal tax rates. In addition, two multiplicative dummies are used, DNOLCRT (DNOL*CRT) controls for the two groups (NOL and non-NOL) of firms which are differently impacted by the corporate tax rate changes and DNOLTREF (DNOL*TREF) variable will be used to capture the effects of the tax reform on NOL firms. A change in corporate tax rates and in the tax legislation should not be associated with a reduction of investment. Hence there is no expected relationship.

\subsection{Data}

The sample of firms is from the Datastream International Ltd (2000) Company Accounts Database (DICA). Annual cross section data from 1982 to 1992 is used. To generate the variables included in the model, information was taken from the DICA balance sheets and profit and loss accounts relative to five years before and after the respective tax reforms. This resulted in a total of 82 firms in USA and 67 firms in Australia. Initially data for 1987 was omitted as it was a transition year for the 1986 TRA in US and the introduction of dividend imputation in Australia. Many companies may

\footnotetext{
${ }^{11}$ Similar to Black et al.(2000) a firm is classified as NOL if it reported an operating loss during the previous year, the current year or the following year.
} 
have changed policies dramatically in this year in anticipation of the changes in the tax law. By removing this year from the sample, any distortions created by these fluctuations are eliminated from the empirical results. ${ }^{12}$ Moreover, only firms that survived for the entire period of analysis (1982 to 1992) and have data in each year in the 5-year pre tax reform period (1982 to 1986) and the 5-year post tax reform period (1988 to 1992) were chosen. If there were missing observations the variables were deleted. This results in a potential survivorship bias. A further problem with the data selection technique is that it resulted a small sample size of 35 firms and 374 observations for the US and 28 firms and 308 observations for Australia. However, this is not inconsistent with previous research. In his seminal paper on dividend behaviour, Lintner (1956) uses a sample of 28 US firms from 1947 to 1953 period, with 196 firm-year observations. Lintner, does point out, his research cannot be used to draw statistical conclusions and as such cannot be generalised.

\subsection{Regression model}

To investigate the empirical hypotheses, the following cross-sectional regression was estimated for both the US and Australia.

$$
\begin{aligned}
\text { INV }_{\text {it }}= & \beta_{0}+\beta_{1} \text { TREF }_{t}+\beta_{2} \text { CRT }_{t}+\beta_{3} \text { ITR }_{t}+\beta_{4} \text { DNOL }_{i t}+\beta_{5} \text { DNOLCTR }_{i t} \\
& +\beta_{6} \text { DNOLTREF }_{\text {it }}+\beta_{7} \text { DE E }_{i t}+\beta_{8} \text { OPR }_{i t}+\beta_{9} \text { DPR }_{\text {it }}+\beta_{10} \text { TREFDPR }_{\text {it }} \\
& +\beta_{11} \text { CIR }_{\text {it }}+\beta_{12} \text { SIZE }_{i t}+\beta_{13} \text { LINV }_{\text {it }}+\varepsilon_{i t}
\end{aligned}
$$

\begin{tabular}{|c|c|}
\hline $\mathrm{INV}_{\mathrm{it}}$ & - Investment measured as the change in Gross PPE plus R\&D divided by sales \\
\hline $\mathrm{TREF}_{\mathrm{t}}$ & Dummy variable to measure the introduction of tax reform at time t. \\
\hline $\mathrm{ITR}_{\mathrm{t}}$ & - Individual tax rate at time $t$. \\
\hline $\mathrm{CRT}_{\mathrm{t}}$ & - Corporate tax rate at time $\mathrm{t}$. \\
\hline $\mathrm{DNOL}_{\text {it }}$ & $\begin{array}{l}\text { - Dummy representing firms with an operating loss. If firm have an operating loss } \\
\text { at time t, DNOL }=1,0 \text { otherwise }\end{array}$ \\
\hline DNOLCTR $_{\text {it }}$ & $\begin{array}{l}\text { - Multiplicative dummy of an operating loss for firm } \mathrm{i} \text {, at time } \mathrm{t} \text { with the corporate tax } \\
\text { rate at time } \mathrm{t} \text {. }\end{array}$ \\
\hline DNOLTREF $_{\text {it }}$ & $\begin{array}{l}\text { - Multiplicative dummy of an operating loss for firm } i \text {, at time } t \text { with the tax reform } \\
\text { dummy at time } t \text {. }\end{array}$ \\
\hline $\mathrm{DE}_{\mathrm{it}}$ & - Debt-to-equity ratio for firm i, at time $t$. \\
\hline $\mathrm{OPR}_{\text {it }}$ & - Operating cash flow ratio for firm $\mathrm{i}$, at time $\mathrm{t}$. \\
\hline $\mathrm{DPR}_{\mathrm{it}}$ & - Dividend payout ratio for firm i, at time $t$. \\
\hline TREFDPR $_{\text {it }}$ & - Multiplicative dummy of TREF dummy with dividend payout ratio for firm i, at time \\
\hline
\end{tabular}

Where:

\footnotetext{
${ }^{12}$ The model was analysed a second time using a sample period which includes the omitted year to see if there were any significant differences. The results were the same as the original model.
} 
CIR $_{\text {it }} \quad-$ Capital intensity ratio for firm $i$, at time $t$.

SIZE $_{\text {it }} \quad-$ Measure for size of firm $i$, as the natural log of total assets at time $t$.

LINV $_{\text {it }} \quad$ - Lagged measure of investment for firm i, at time $t$.

\subsection{Results}

\subsection{Descriptive statistics}

Table 2 reports the descriptive statistics associated with the dependent variable and the independent variables for the regression model. Of particular relevance the mean of Corporate Investment (INV), Operating Cash Flow (OPR) and Capital Intensity Ratio (CIR) were higher in Australia while Debt to Equity ratio (DE) was higher in the US.

Table 2: Descriptve Statistics of Regression variables

\begin{tabular}{|l|c|c|c|c|c|c|c|c|c|c|}
\hline USA & INV? & DNOL? & DE? & OPR? & DPR? & CIR? & SIZE? & LINV? & PPE? & RD? \\
\hline Mean & 0.103 & 0.094 & 0.353 & 0.025 & 0.270 & 0.276 & 4.649 & 0.103 & 448.403 & 76.398 \\
\hline Median & 0.059 & 0.000 & 0.213 & 0.072 & 0.300 & 0.269 & 4.448 & 0.059 & 38.493 & 19.359 \\
\hline Std. Dev. & 0.273 & 0.292 & 1.943 & 0.348 & 1.999 & 0.132 & 1.594 & 0.273 & 1335.860 & 170.365 \\
\hline Observations & 374 & 374 & 374 & 374 & 374 & 374 & 374 & 374 & 374 & 374 \\
\hline
\end{tabular}

\begin{tabular}{|l|c|c|c|c|c|c|c|c|c|c|}
\hline Australia & INV? & DNOL? & DE? & OPR? & DPR? & CIR? & SIZE? & LINV? & PPE? & RD? \\
\hline Mean & 1.227 & 0.101 & 0.347 & 0.121 & 0.489 & 0.391 & 6.549 & 0.834 & 919.978 & 4.770 \\
\hline Median & 0.119 & 0.000 & 0.265 & 0.093 & 0.520 & 0.329 & 6.468 & 0.080 & 150.975 & 0.728 \\
\hline Std. Dev. & 3.476 & 0.301 & 0.352 & 0.165 & 0.602 & 0.686 & 1.341 & 3.087 & 2061.727 & 19.038 \\
\hline Observations & 308 & 308 & 308 & 308 & 308 & 308 & 308 & 308 & 308 & 308 \\
\hline
\end{tabular}

Table 3 provides a Pairwise correlation analysis of the variables being used in the regression model to check for any correlations which could affect the result of this study. Based on the table results, it is unlikely that multicollinearity will be an issue in the regression analysis. Of particular relevance is the high negative correlation between TREF which measures the effect of tax reform with the corporate income tax rate and the individual tax rate. However the non-inclusion of these variables will make it difficult to distinguish between the tax reform and the statutory tax rate changes which occurred concurrently. For the other variables there do not appear to be significant partial correlations. 
Table 3: Pairwise Correlation Analysis

\section{USA}

\begin{tabular}{|c|c|c|c|c|c|c|c|c|c|c|c|}
\hline & $I N V$ & TREF & $D N O L$ & $C R T$ & ITR & $D E$ & $O P R$ & $D P R$ & $C I R$ & SIZE & $L I N V$ \\
\hline INV & 1 & & & & & & & & & & \\
\hline TREF & -0.02121 & 1 & & & & & & & & & \\
\hline DNOL & 0.246788 & 0.102974 & 1 & & & & & & & & \\
\hline CRT & 0.021215 & -1 & -0.10297 & 1 & & & & & & & \\
\hline ITR & 0.037046 & -0.96136 & -0.10253 & 0.961359 & 1 & & & & & & \\
\hline $\mathrm{DE}$ & -0.01867 & 0.043066 & -0.07697 & -0.04307 & -0.06008 & 1 & & & & & \\
\hline OPR & -0.76426 & 0.03585 & -0.36818 & -0.03585 & -0.05288 & 0.038359 & 1 & & & & \\
\hline DPR & -0.00393 & -0.03664 & -0.00148 & 0.036637 & 0.027807 & 0.028815 & 0.003211 & 1 & & & \\
\hline CIR & -0.08109 & -0.01163 & 0.014233 & 0.011634 & 0.012578 & -0.02665 & 0.103066 & 0.020422 & 1 & & \\
\hline SIZE & -0.05784 & 0.087137 & 0.020294 & -0.08714 & -0.09074 & -0.00491 & 0.022644 & 0.038078 & -0.14295 & 1 & \\
\hline LINV & 0.646854 & 0.033918 & 0.253154 & -0.03392 & -0.02819 & -0.05428 & -0.47184 & -0.00595 & -0.07551 & -0.03641 & 1 \\
\hline
\end{tabular}

\section{Australia}

\begin{tabular}{|c|c|c|c|c|c|c|c|c|c|c|c|}
\hline & $I N V$ & TREF & $D N O L$ & $C R T$ & ITR & $D E$ & $O P R$ & $D P R$ & $C I R$ & SIZE & LINV \\
\hline INV & 1 & & & & & & & & & & \\
\hline TREF & 0.323634 & 1 & & & & & & & & & \\
\hline DNOL & 0.026628 & 0.199257 & 1 & & & & & & & & \\
\hline CRT & -0.32363 & -1 & -0.19926 & 1 & & & & & & & \\
\hline ITR & -0.3345 & -0.99504 & -0.18885 & 0.995044 & 1 & & & & & & \\
\hline $\mathrm{DE}$ & 0.077919 & 0.074385 & -0.07491 & -0.07439 & -0.07619 & 1 & & & & & \\
\hline OPR & -0.01747 & -0.0424 & -0.08109 & 0.042401 & 0.040853 & -0.07667 & 1 & & & & \\
\hline DPR & 0.064041 & -0.00319 & 0.071132 & 0.003186 & 0.003993 & -0.03092 & 0.045246 & 1 & & & \\
\hline CIR & -0.02619 & -0.07829 & -0.04579 & 0.078293 & 0.082201 & -0.05558 & -0.07214 & 0.006499 & 1 & & \\
\hline SIZE & 0.038194 & 0.276647 & -0.0445 & -0.27665 & -0.27301 & 0.017076 & 0.130956 & -0.00933 & -0.08403 & 1 & \\
\hline LINV & -0.0093 & 0.149774 & 0.057988 & -0.14977 & -0.14022 & -0.07782 & 0.08048 & 0.038486 & -0.06699 & 0.101184 & 1 \\
\hline
\end{tabular}




\subsection{Regression Results}

Table 4 reports the results of OLS regressions carried out on each country's data. These regressions were partly carried out to ascertain whether subsequent "pooling" of the data is appropriate. The regression analysis is extended in Table 5 by pooling the data and estimating the fixed effect specification. This model controls for firm and year specific effects which may drive the results from the OLS model. Using a fixed effects model, but otherwise all common coefficients and no weighting appears to be more appropriate than the OLS estimates which may pick up correlation between firms. Firm differences are modelled only with different intercept terms for each equation, other coefficients and error variances are assumed to be the same. Harris and Kemsley (1999) use the fixed-effects model in their analysis to eliminate the possibility that a "mean cross-firm effect from any correlated omitted variable relating to risk, age, growth, or industry explains the primary results."

The results presented in Table 4 indicate that between 10 to 58 percent of the variation in INV can be explained. In general, the coefficients are stable across time, suggesting that pooling of the separate individual firms is indeed appropriate. An initial review of the OLS results in Table 4 reveals that the TREF coefficient in the US has a positive sign and is not significant. This is contrary to expectations. Based on this result it appears that hypothesis $\left(\mathrm{H}_{2}\right)$ which states that TRA had a negative impact on corporate investment in the US, is incorrect. A redundant variable test ${ }^{13}$ was then performed. The results, indicate that TREF $(\mathrm{F}=0.6327)$ does not contribute significantly to the model. On the other hand, Table 4 tends to support hypothesis $\left(\mathrm{H}_{1} \mathrm{~A}\right)$, as evidenced by the positive sign of the TREF coefficient for Australia. Even the magnitude of the estimated coefficient $(\mathrm{p}=0.06)$ are feasible and suggestive of increased corporate investment due to dividend imputation.

\footnotetext{
${ }^{13}$ This test compares the estimated likelihood of the full model and the estimated likelihood of a reduced model which does not include the variable.
} 
Table 4: OLS regression for USA and Australia

\begin{tabular}{|c|c|c|c|c|c|}
\hline \multirow{2}{*}{$\frac{\text { Dependent Variable }}{\text { Variable }}$} & \multirow{2}{*}{$\frac{\text { INV }}{\text { Expected Sign }}$} & \multicolumn{2}{|c|}{ US } & \multicolumn{2}{|c|}{ Australia } \\
\hline & & Coefficient & P-value & Coefficient & P-value \\
\hline $\mathrm{C}$ & $?$ & -0.01116 & 0.9512 & -30.5784 & 0.1645 \\
\hline TREF & $-/+$ & 0.019428 & 0.6327 & 8.799041 & 0.0571 \\
\hline CRT & ? & 0.083486 & 0.8421 & -1.82212 & $0.8395^{*}$ \\
\hline ITR & $?$ & 0.141197 & 0.213 & 53.948 & 0.1765 \\
\hline DNOL & $?$ & 0.102596 & 0.8706 & -1.82333 & 0.8998 \\
\hline DNOLCRT & $?$ & -0.41855 & 0.7664 & 4.252244 & 0.8963 \\
\hline DNOLTREF & $?$ & -0.00351 & 0.9818 & -0.24094 & 0.945 \\
\hline $\mathrm{DE}$ & ? & 0.002562 & 0.5379 & 0.462771 & 0.4617 \\
\hline OPR & + & -0.46516 & 0 & 0.098979 & 0.9362 \\
\hline DPR & - & 0.001415 & 0.9511 & 0.090818 & 0.9551 \\
\hline TREFDPR & + & -0.00147 & 0.95 & 0.352843 & 0.8305 \\
\hline CIR & + & 0.001764 & 0.978 & -0.0149 & 0.9595 \\
\hline SIZE & $?$ & -0.00437 & 0.4169 & -0.15244 & 0.3682 \\
\hline LINV & + & 0.329503 & $0 * * *$ & -0.05199 & 0.4045 \\
\hline Adjusted R-squared & & 0.58628 & & 0.08549 & \\
\hline F-statistic & & 39.04354 & & 3.006275 & \\
\hline Durbin-Watson & & 2.009774 & & 1.930967 & \\
\hline
\end{tabular}

*p $<0.10$ significant at the 10 percent level

$* * \mathrm{p}<0.05$ significant at the 5 percent level

$* * * \mathrm{p} \quad<0.01$ significant at the 1 percent level 
The fixed-effect estimates as presented in Table $5^{14}$ indicates the model is significant for both the US (F=41.25) and Australia $(F=41.40)$, suggesting that this is the more appropriate model. For the US the equation has an explanatory power (adjusted $\mathrm{R}^{2}$ ) of $84.7 \%$, while for Australia it has an explanatory power (adjusted $\mathrm{R}^{2}$ ) of $89.01 \%$. This implies that the models were adequately specified. The Durbin-Watson statistic is 1.41 for the US and 1.10 for Australia. The low DW value for the US may be a result of the nature of cross-sectional estimates, which may pick up correlation between firms. It may be realistic to expect different error variances for the different cross-sections. For example, Greene (2000) notes that for a cross- country comparison there may be variation in the scales of the variables in the model. Visual inspections of the residuals consistent with White (1980) and Breusch and Pagan (1979) indicates that heteroskedasticity is present. Consequently, the numbers in parentheses in Table 4 are White (1980) adjusted values.

\subsection{Regression Results for US}

The US 1986 tax reform mainly consisted of the repeal of the tax credit, repeal of the preferential treatment afforded to capital gains and the extension of depreciation allowances. The negative coefficient of TREF (-0.2115) observed from the regression results is consistent with what was hypothesised (hypothesis 2). Theoretically it was expected that these changes in the 1986 tax reform will have a negative impact on corporate investment. This coefficient was significant indicating that it did have a major effect on corporate investment from the other variables of primary interest in this study CRT and ITR, measuring the corporate tax rate and the individual tax rate changes respectively, which both occurred in the US at the same time as when the 1986 tax reform was implemented, only ITR was significant. This indicates that the decrease of ITR at the same time the 1986 tax reform was implemented had a negative impact on corporate investment. CRT was found not to have any statistical significance on corporate investment.

\footnotetext{
${ }^{14}$ Originally, the models also included a CRT, TREFDPR, CIR and SIZE variables. The increase in the adjusted $\mathrm{R}^{2}$ for the model which includes these variables shows only a .01 percent increase for the US and only a .04 percent increase for Australia. A redundant variables test reveals that these variables had no statistical significance. Therefore, the final model did not include these variables.
} 
The variable DNOL which measures the impact on NOL firms was negative and significant. This shows that NOL (earning status) firms were negatively related to current corporate investment in US. However, the variables DNOLCRT and DNOLTREF which measures the effect of the tax reform and the change in corporate tax rates respectively on firms having an operating loss in a particular year is positive and significant. This indicates that the tax reform and corporate tax rates decrease had a positive impact on corporate investment for NOL firms. With inference to this result it can be deduced that the 1986 tax reform has resulted in a lower marginal tax rate for NOL firms.

\subsection{Regression Results for Australia}

The Australian dividend tax reform mainly consisted of the elimination of double taxation. Essentially, the Australian imputation system operates by allowing income tax paid at the corporate level to be passed to shareholders in the form of imputation credits. It was hypothesised (hypothesis $\mathrm{H}_{1} \mathrm{~A}$ ) that if the positive effects of dividend imputation on shareholder returns exceeded the negative effects of capital gain taxes on shareholder returns, corporate capital investment in Australia would increase after the tax reform. The result supports this hypothesis with TREF having a positive coefficient and is significant at the one percent level. For the other variables of interest in this study CRT and ITR, similar to the US only ITR was positive and significant while CRT did not have any statistical significance in measuring corporate investment. DNOL and DNOLCRT were significant while DNOLTREF was insignificant in Australia. This indicates that dividend imputation had a negative impact on corporate investment while the decrease in corporate tax rates had a positive impact on corporate investment for NOL firms. Hence it can be inferred from these results that the introduction of dividend imputation in Australia had an overall positive impact on corporate investment. 
Table 5: Pooled Regression estimate for USA and Australia

\begin{tabular}{|c|c|c|c|c|c|}
\hline $\begin{array}{l}\text { Dependent } \\
\text { Variable: }\end{array}$ & & $\begin{array}{l}\text { USA } \\
(\text { INV? })^{\wedge} \mathbf{2}\end{array}$ & & $\begin{array}{l}\text { Australia } \\
\text { LOG(INV?) }\end{array}$ & \\
\hline & $\begin{array}{l}\text { Expected } \\
\text { sign }\end{array}$ & Coefficient & Prob. & Coefficient & Prob. \\
\hline TREF? & $-/+$ & -0.21154 & $\begin{array}{c}0.2761 \\
(0.0431)^{* *}\end{array}$ & 5.577467 & $\begin{array}{c}0 * * * \\
(0)^{* * *}\end{array}$ \\
\hline ITR? & $?$ & -0.91589 & $\begin{array}{c}0.3224 \\
(0.0667)^{*}\end{array}$ & 25.48551 & $\begin{array}{c}0 * * * \\
(0)^{* * *}\end{array}$ \\
\hline DNOL? & $?$ & -2.11627 & $\begin{array}{c}0.0037 * * * \\
(0.1036)\end{array}$ & -4.53416 & $\begin{array}{c}0.0063 * * * \\
(0.0002)^{* * *}\end{array}$ \\
\hline DNOLCRT? & $?$ & 3.69542 & $\begin{array}{c}0.0189 * * * \\
(0.1765)\end{array}$ & 10.99146 & $\begin{array}{c}0.016 * * * \\
(0.0006)^{* * *}\end{array}$ \\
\hline DNOLTREF? & $?$ & 0.585059 & $\begin{array}{c}0 * * * \\
(0.03)\end{array}$ & 0.342007 & $\begin{array}{c}0.2014 \\
(0.2314)\end{array}$ \\
\hline DE? & $?$ & 0.002926 & $\begin{array}{c}0.5431 \\
(0.0424)^{* *}\end{array}$ & -0.3364 & $\begin{array}{c}0.3268 \\
(0.2561)\end{array}$ \\
\hline OPR? & + & -1.32273 & $\begin{array}{c}0 * * * \\
(0)^{* * *}\end{array}$ & -1.36999 & $\begin{array}{c}0.0027 * * * \\
(0) * * *\end{array}$ \\
\hline DPR? & - & 0.000458 & $\begin{array}{c}0.9235 \\
(0.7068)\end{array}$ & -0.02416 & $\begin{array}{c}0.7908 \\
(0.4282)\end{array}$ \\
\hline LINV & + & 0.131717 & $\begin{array}{c}0.0556 * * * \\
(0.2839)\end{array}$ & 0.049747 & $\begin{array}{c}0.0091 \\
(0.0008)\end{array}$ \\
\hline
\end{tabular}

\begin{tabular}{ccc}
\hline $\begin{array}{c}\text { Adjusted R- } \\
\text { squared }\end{array}$ & 0.847158 & 0.89012 \\
F-statistic & 41.25064 & 41.40413 \\
Durbin-Watson & 1.416159 & 1.103178 \\
\hline White adjusted p-values are shown in bracket with $p<0.10=*, p<0.05=* *, p<0.01=* * *$
\end{tabular}




\subsection{Regression result for Control variables}

As for the control variables, OPR which measures the operating cash flow ratio has a significant and negative impact on investment in both US and Australia. Similarly LINV which is a measure of the lag term of capital investment is significant and positively related to current capital investment in both the US and Australia. Finally DE which measures the debt to equity ratio was positive and significant in the US only. This provides some evidence that financial leverage influences corporate capital investment in the US.

\subsection{Summary and Concluding remarks}

This paper has conducted an empirical investigation of the effects of tax reform on corporate investment in the US and Australia. The Tax Reform Act of 1986 in the US and dividend imputation in Australia affects the tax regime in which corporations operate and provide a rich testing ground for the impact of tax reforms on corporate investment. This paper also examines the determinants of corporate investment changes surrounding the enactment of the TRA act and dividend imputation. Some non-tax control variables that might affect corporate investment are also analysed. This increases the power of the regression tests, leading to more conclusive results. Most of the same variables were included in the final model of the US and Australia. Finally, the results provide support for both hypotheses tested.

Specifically, the findings of this paper support the assertions of Black et al. (2000), Harberger (1962) and Morck (2003) that dividend imputation as introduced in Australia was an effective way to reduce the distortions caused by the traditional system of double taxation as currently in place in the US. The results provide evidence that the introduction of the TRA had a negative impact on corporate investment. Futhermore, this paper provides evidence that individual taxes play a significant role in corporate investment decisions in both the US and Australia. Based on these results it can be inferred that both the 1986 TRA and the dividend imputation do have an effect on corporate capital investment. 


\section{References}

Abrutyn, S., Turner, R. 1990. Taxes and firms' dividend policies: Survey results. National Tax Journal 43, 491-496.

Anderson, L. 1964. Corporate finance and fixed investment: An econometric study: Division of Research, Graduate school of Business Administration, Harvard University.

Bellamy, D. 1994. Evidence of imputation clienteles in the australian equity market. Asia Pacific Journal of Management 11, 275-287.

Black, E., Legoria, J., Sellers, K. 2000. Capital investment effects of dividend imputation. Journal of The American Taxation Association 22, 40-59.

Bolster, P., Janjigian, V. 1991. Dividend policy and valuation effects of the tax reform act of 1986. National Tax Journal, 511-518.

Breusch, T., Pagan, A. 1979. A simplest test for heteroskedaticity. Econometricia, 12871294.

Callihan, D. 1994. Corporate effective tax rates: A synthesis of the literature. Journal of Accounting Literature 13, 1-43.

Datastream International Ltd. 2000. Datastream advance version 3.5. London.

Dhrymes, P., Kurz, M. 1967. Investments, dividends and external finance behaviour of firms. In R. Ferber (Ed.), Determinants of investment behaviour. Columbia University Press: New York.

Fama, E. 1974. The empirical relationships between the dividend and investment decisions of firms. American Economic Review 64, 304-318.

Gilchrist, S., Himmelberg, C. 1995. Evidence on the role of cash flow for investment. Journal of Monetary Economics 36, 541-572.

Gravelle, G. 1991. Corporate tax integration: Issues and options,. Congressional research services report for congress: Washington D.C.

Greene, W. 2000. Econometric analysis (4 ed.): Prentice Hall.

Gupta, S., Newberry, K. 1997a. Determinants of the variability in corporate effective tax rates: Evidence from longitudinal data. Journal of Accounting and Public Policy $16,1-34$.

Gupta, S., Newberry, K. 1997b. Determinants of the variability in corporate effective tax rates: Evidence from longitudinal data. Journal of Accounting and Public Policy $16,1-34$.

Hamson, D., Ziegler, P. 1990. The impact of dividend imputation on firms' financial decisions. Accounting and Finance 30, 29-53.

Harberger, A. 1962. The incidence of corporate income tax. Journal of political economy 70, 215-240.

Harris, T., Kemsley, D. 1999. Dividend taxation in firm valuation: New evidence. Journal of Accounting Research 37, 275-291.

Heming, T. 1994. The effect of dividend imputation on the payout ratios of australian companies. Australian Tax Forum 11, 203-227.

Higgins, R. 1972. The corporate dividend-savings decision. Journal of Financial and Quantitative Analysis 7, 1527-1541. 
Kari, S., Ylä-Liedenpohja, J. 2002. Classical corporation tax as a global means of tax harmonization. University of Munich Centre for Economic Studies and the IFO Institute for Economic Research 665.

Kinney, M., Trezevant, R. 1993. Taxes and the timing of corporate capital expenditures. Journal of American Taxation Association 15.

Lintner, J. 1956. Distribution of income of corporations among dividends, retained earnings and taxes. American Economic Review 46, 97-118.

Lintner, J. 1967. Corporate finance: Risk and investment, Determinants of investment behaviour. National Bureau of Economic Research: New York.

McCabe, G. 1979. The empirical relationships between investment and financing: A new look. Journal of Financial and Quantitative Analysis 14, 119-135.

McDonald, J., Jacquillet, B., Nussenbaum, M. 1975. Dividend, investment and financing decisions: Empirical evidence on french firms. Journal of Financial and Quatitative Analysis 7.

Means, D., Charoenwong, C., Kang, Y. 1992. Changing dividend policies caused by the tax reform act of 1986: An empirical analysis. Journal of Economics and Finance 16, 153-160.

Meyer, J., Glauber, R. 1964. Investment decisions, economic forecasting and public policy: Harvard University Press. Boston.

Meyer, J., Kuh, E. 1957. The investment decision: Harvard University Press. Boston.

Modigliani, F., Miller, M. 1958. The cost of capital, corporate finance and theory investment. American Economic Review 261-297.

Morck, R. 2003. Why some double taxation might make sense: The special case of intercorporate dividends. Working Paper Series National Bureau of Economic Research 9651.

Mueller, D. 1967. The firm decision process: An econometric investigation. Quarterly Journal of Business and Economics, 5887.

Peterson, P., Benesh, G. 1983. A re-examination of the empirical relationship between investment and financing decisions. Thr Journal of Financial and Quantitative Analysis 18, 439-453.

Stickney, C., McGee, V. 1982. Effective corporate tax rates: The effect of size, capital intensity, leverage, and other factors. Journal of Accounting and Public Policy 1, 125-152.

White, H. 1980. A heteroskedasticity-consistent covariance matrix estimator and a direct test of heteroskedasticity. Econometricia 48, 817-838. 